\title{
THE VISUAL STUDENTS' PROBLEMS IN LISTENING CLASS AT THE THIRD SEMESTER STUDENTS OF IAIN MADURA
}

\author{
Isrok Wulandari \\ English Teaching and Learning Program, Tarbiyah Faculty, IAIN Madura \\ Kristanti Ayuanita \\ English Teaching and Learning Program, Tarbiyah Faculty, IAIN Madura
}

\begin{abstract}
All of the students that have different learning style learn in listening class include the visuals students. This research investigates: how the visual students learn in listening class at the third-semester students of IAIN Madura (Previously STAIN Pamekasan) and what kind of difficulties faced by visual students in listening class and what factors that make the visual students difficult to comprehend the material in listening class. This is qualitative research. The researcher obtained the data through observation, interview and documentation. The results of this research are the visual students in listening class like doodle and some of them like movies. The difficulties faced by the visual students in listening class are: difficult to answer the question directly and difficult to concentrate when they listened the material. The most factor that makes the visual students difficult to comprehend the material because the situation is crowded. From this research, it is also found that not all of the visual students in listening class like watch movies have a problem or difficult with the verbal or oral instruction, they loss their concentration and can learn in the noise or crowded situation of listening class.
\end{abstract}

Keywords: Problems; Visual Learner Students; Listening

First Received:

September $4^{\text {th }}, 2019$
Final Proof Received: September 09th, 2019

\section{INTRODUCTION}

State of Islamic College (STAIN) Pamekasan, the former name of IAIN Madura is one of the colleges in Pamekasan and the only State of Islamic College in Madura. There are eight major programs and one of them is English Teaching Learning Program. Over there teach many subjects related to English language, such as reading, speaking, writing, phonology, morphology included listening is one of the subjects taught there.

"In 1996 the members of the International Listening Association adopted the following definition as quoted by Debra L Worthington \& Margaret E. Fitch Hauser (2012: 5): listening is the process of receiving, constructing meaning from and responding to spoken and or nonverbal message."

Based on these definitions we can conclude that listening is the process of hearing, receiving, and understanding of message. So we can receive and understand what others say then we give respond to others. Listening is one of the fourth skills in English that must be mastered by all English students Teaching Learning Program because it is the key to learning language.

Every student in English department has different intelligences. According to Professor Howard Gardner in the Mike's book Intelligence is a biopsychological potential 
to process information that can be activated in a cultural setting to solve problems or create products that are of value in a culture (Fleetham, 2006: 17).

Based on the expert's statement above intelligence is the ability that owned by human and the ability to comprehend their environment to carry out their knowledge and skill. According to Gardner as quoted by Eva, he listed seven of intelligences: Musical/ Rhythmic, Verbal/ Linguistics, Visual/ Spatial, Bodily/ Kinesthetic, Logical/ Mathematical, Intrapersonal and Interpersonal. All people have all of these intelligences, he said, but in each Pearson one (or more) of them is more pronounced (Rabbianty, 2013: 46).

In listening class English students learn based on their learning style or intelligences. We know that not only Verbal/Linguistics students learn in listening class but also all students that have different intelligences learn it too. Visual/ Spatial is one of intelligence that owned by English students.

"Howard Gardner (1983: 182) said that the central to spatial intelligence are the capacities to perceive the visual world accurately, to perform transformations and modifications upon one's initial perceptions, and to be able to re-create aspects of one's visual experience, even in the absence of relevant physical stimuli."

So, Visual/Spatial students can learn by visual word or think in picture and image. But in fact, the Visual/Spatial students can learn and comprehend in listening class. Actually listening is without seeing the word, pictures and others.

Based on the discussion above the researcher interested to research the problem of visual students in listening class because to know how the visual students comprehend the material in listening class exactly in listening comprehension.

Aista Rahmadhani has research The Effect of Blind Map as the Instructional Media on Students Listening Comprehension of Seventh Grade of SMPN 5 Pamekasan (Rahmadhani, 2013). While the other researcher, Siti Maufiroh has research about Some Problem in LearningListeningComprehension Faced by The Eight Grade Students at MTs Al-Falah Al-Islami Bancelok Jrengik Sampang (Maufiroh, 2012). Whereas in my research about the problem of visual students in listening class and the researcher notify that in this research different in discussing and the objective with the previous research.

Based on the phenomenon above, the researcher interested and want to know the problem of the visual students in listening class. The title of this research is "The Visual Learner Students' Problems in Listening Class at the Third Semester Students of IAIN Madura".

\section{LITERATURE REVIEW}

\section{Listening}

\section{The Definition of Listening}

According to F. Alton Everest Listening is a psychophysical, subjective activity. Listening critically inevitably relates the activity to physical things such as amplifiers, microphones, loudspeakers, and environment (Everest, 2007: 2). 
Listening is the first skill that can be mastered by the students because listening skill influence to the others skill such as speaking, reading and writing. If the students cannot listen so they cannot respond to others exactly to speak.

"This is agreeable with Debra L Worthington \& Margaret E. Fitch Hauser (2012: 3)opinions. They state that listening is a critical life competency is it is fundamental to all other communication competencies-speaking, writing, and reading. of these competencies, listening is the first communication skill we acquire and use. In fact, we began to listen before we were born."

From those definition above the researcher can conclude that listening is the most important skill in learning language because affecting to others skill.

\section{Learning Style}

\section{a. Definition of Learning Style}

The success of learning decided by the way or method learning used called as learning style. Learning style is the way that the students prefers when they do the thinking activity, processing and understanding the information (Gunawan, 2004: 139). Means learning style is the way that used by the students when they learn or acquire the knowledge or information. Tilly Mortimore (2008: 6) said that learning style is seen more in terms of the strategies a student adopts to cope with learning tasks and situations.

\section{b. Kinds of Learning Style}

Every student has learning style, but a few students have dominant's learning style. Adi W. Gunawan (2004: 134) states that the result of research indicate that the students study by using their dominant learning style, when they do the assignment will achieve the higher score than they do not study by using their learning style. Based on the preference sensories, learning style divide into three: visual, auditory and kinesthethic. While based on the intelligence Howard Gardner state that human have eight intelligences as called multiple intelligences. Multiple intelligence include to the learning style because the students learn by using their intelligence. So the intelligence as the way to get the information.

Visual learners easy to see and imagine what it said. They usually look the picture that related with the word and they will understand the information if they look the event. They like look the information in a written form and in a picture.

Auditory learners they usually express their self through a voice, whether they do internal communication by their self and external communication with others. They will hear a voice from what will they write.

Kinesthetic learners are very sensitive with feeling or emotion to the sensation movement. If they want to write a word, they will feel the word first after that they will write it. They like learn if related with physique and movement. 


\section{Visual/Spatial Intelligence}

a. Definition of Spatial/Visual Intelligence

According to Howard Gardner (1983: 182) spatial intelligence is the ability to comprehend a form or an object directly, transform and modification initial perceptions and to be able to re-create aspects of one's visual experience that relevant with physical stimuli.

Means that this intelligence is the ability to comprehend something in a form and concrete object such as picture, word and others then modification it. And also the ability to create experience visually that related with stimulus physically.

Thurstone in the Gardner's book strengthen his conclusion that there is something special about spatial ability. Thurstone divide spatial ability into three components (Gardner, 1983: 184): the first is the ability to recognize the identity of an object when it is seen from different side, second is the ability to imagine movement between the parts of an arrangement, and the last is the ability to think about something that relation with spatial picture.

According to Gardner (1983: 185) that spatial intelligence involves four capacities, they are: the ability to recognize an example of the same element, the ability to transform or to recognize a transformation of one element into another, the capacity to modify mental imagery and then to transform that imagery, and the capacity to produce a graphic illustration of spatial information. These abilities are clearly not identical the individual may be saying in visual perception or having little ability to draw and imagine something.

b. Characteristics of Spatial/Visual Learners

According to Bobbi DePorter in the Quantum Teaching (2000: 216), characteristics of visual learners are their best learning when they begin with the whole pictures, do general observation about teaching material, reading the material and they use mind mapping when they learn something.

Many others characteristics of visual learners, in the Quantum Learning Bobbi DePorter and Mike Henarcki (2000: 116) state that the characteristics visual learners are neat and settled, speak quickly, a good a planner and organizer, precise in detail, prioritize the performance and presentation, good spelling and see the word in their mind, memorize what they seen, memorize with visualize, they can learn in the noise situation, having problem with verbal instruction except in the written form and ask someone to repeat it, fast reader and diligent, they like reading, need observation and complete purpose, heedful behavior before they believe about one problem, doodling when telephone and in the meeting, forget to deliver verbal message to others, answer the question with "yes or no", like to do demonstration than to give a speech, like art than music, they know what will they say but difficult to select the word, and sometimes, they loss their concentration when want to give attention. 
Thomas R Hoerr (2000: 6) identify that visual learners love doodle, paint or draw; create three dimensional representations; look at and create maps and diagrams; take things apart and put them back together, images, pictures designing, drawing, and visualizing.

\section{METHOD}

The researcher uses qualitative approach in this research. This research collects the descriptive data in the form of report and description. Bogdan and Taylor in Lexy's book said that procedure of research produce the descriptive data having a form word in written or verbal from people and behavior that we can seen (Moleong, 2008: 4). The researcher uses descriptive qualitative approach because in this research explains and describe clearly about the problem of spatial/visual students in listening class at third semester of IAIN Madura in the form of word, images and not in numerical data (Creswell, 2012: 247). The researcher take place at IAIN Madura (Previously STAIN Pamekasan), Data source in this research are the college students and English lecturer in listening class at third semester of IAIN Madura.

Non participant observation was used to observe all activities, event and process of learning in the listening class at third semester of IAIN Madura. Unstructured interview was used by researcher in this research. The researcher also uses documentation to get the valid data from list attendance of listening students at third semester of IAIN Madura, the form of value of students in listening class and photograph when in the teaching learning process as well as photos of the finding in the field. Researcher also uses questionnaire because want to know which the visual students in listening class at third semester. The researcher applied closed - ended questionnaire, means that the researcher determined the answer so that the informant just choose one of the answer. The questionnaire is about the characteristics of visual students. So from the answer of students the researcher can know which the visual students. To analyze the data, the researcher applied three steps of data analysis by Miles and Huberman (Miles \& Huberman, 1994), they were data reduction, data display, and conclusion drawing. Triangulation of data source and member checking were used to ensure that the data valid.

\section{RESULTS AND DISCUSSION}

\section{How the Visual Students Learning in Listening Class at the Third Semester Students of IAIN Madura.}

From all statement of sixteen visual students in $\mathrm{F}$ listening class at the third semester students of IAIN Madura above. The researcher can explain that the visual studentsin F listening class like doodle or write the important something for them. Sometimes, they write the vocab, the meaning and dialogue. Because it helps them to more understand the material. 
Beside that, they look for the meaning of new vocab in the dictionary or ask to their friend. Sometimes, the lecturer ask them to fill their handout. Usually, they talk and discuss with their friend about the work or the meaning. Pay attention to the lecturer and a book, it helps them to more understand the material. They try to focus and concentration what they heard. Some of them silent and more concentration to understand the material. Some of the statement of sixteen the visual students in F listening class are:

This is the statement from Nurul Isnaini:

"I focused to listen the material, I saw to my lecturer and my book. Sometime, I saw my friend. Beside that, I wrote the new vocab and the others. Making me more understand, I learnt the material first before started to listen (Isnaini, 2014)."

That statement same with R. Ali Mahdum Davir' statement:

"When I listened to the material, I always paid attention to my lecturer because if I just listened, I wouldn't get anything. So, I might see to the lecturer directly. I could not get the point if I didnot see something when I listened to the materials. I needed to see the picture or object that related with the material. And when the lecturer explained more about the material, so it helped me to understand it (Davir, 2014)."

That statement same with Muhammad Hifni, that is:

"I wrote something when I listened. It couldbe the vocab, dialogue from the cassete and others. I tried to listen the material seriously. Sometimes, I moved my body but I still focused what I heard. And I always paid attention to my lecturer (Hifni, 2014)."

All of the statement above strengthened with the direct observation by the researcher in the field. That are:

Nurul Isnaini (31):

When she listened to the material, she paid attention to the lecturer, a book, doodled and sometimes looked around to her friends.

R. Ali Mahdum Davir (32):

He paid attention to the lecturer when he listened to the material, doodled and he always bowed.

Muhammad Hifni (24):

He focused to listen to the material and saw to the picture. He sometime moved his body but still focused to listen.

From the statements of visual students in $\mathrm{F}$ listening class at the third semester students of IAIN Madura above, those statement same with explanation or statement from Mrs. Kristanti Ayuanita, she is a lecturer of listening class. She state that:

"Generally, all of my students tried to listen because if they did not listen, so they could lose the material. Sometimes, they wrote the vocab or dialogue, doodled something in their book and they filled their handout. Beside that, they talked with their friend, discussed about the work, and the meaning when they listened in the listening class (Ayuanita, 2014)."

Means that, her lecturer explains that her students like doodle in their book, write the vocab and dialogue when they listen to the material. 


\section{Many Kind of Difficulties Faced by the Visual Students in Listening Class at the Third Semester Students of IAIN Madura.}

Many kinds of difficulties faced by the visual students in F listening class at the third semester students of IAIN Madura. They are difficult to concentration in the listening class and they do not understand the previous material so difficult to continuo other material. They get difficulty to focus listen and they difficult to answer the question from lecturer directly, they do not understand what the speaker said, they are difficult to understand the vocabulary, they are difficult to find the meaning, they like look the picture and watch movie but in listening class the lecturer seldom give them it. They are difficult to get the point. They can not understand the material quickly. They are also difficult to understand the pronounciation, and the last, the material is very difficult is very difficult for them.

The researcher got those explanation from direct interview with sixteen visual students of $\mathrm{F}$ listening class. Some of them are:

The statement from Nurul Isnaini:

"I was difficult to concentrate. I did not understand the previous material, so I was difficult to understand the next material. I was difficult to know the vocab and the meaning. If my lecturer gave me oral assignment, it was very difficult to me. Because I just had limited time to think. I like written assignment because I could imagine the answer (Isnaini, 2014)."

That statement same with statement from Istiana is:

"I like watched movie than just listening that did not see anything. I was difficult to know the meaning and my concentration was easy to disturb. I like written assignment because better for me. Oral assignment was difficult to me (Istiana, 2014)."

The statement from Muhammad Hifni is:

"I did not understand what the speaker said. The vocab seldom to use. So, I did not know the meaning. I was difficult to do the work. I like written assignment because I had time to guest the answer (Hifni, 2014)."

The statement above strengthened with the direct observation by the researcher in the field. That is:

Nurul Isnaini (31):

When she listened to the material in listening class, she did not look quiet.

Istiana (7):

She wrote the vocab and looked for the meaning in the dictionary.

Muhammad Hifni (24):

He moved his body to make him more focused to listen the speaker because he did not understand what the speaker said.

All of the statement above same with the statement from her lecturer, Mrs. Kristanti Ayuanita said that: 
"They were difficult to understand the word, the vocab and the meaning. They did not like listening. They interested to another skill of language. They were difficult to understand the material (Ayuanita, 2014)."

Means that some her students are difficult to understand the material.

\section{Some Factors That Make the Visual Students Difficult to Comprehend the Material}

Many factors that make the visual students in F listening class at the third semester students of IAIN Madura are difficult to understand the material. All of the difficulties faced by the visual students caused by some of them donot like listening, they seldom listen to the native speaker and they interest to another skill of language, they cannot hear the voice of speaker clearly and there is noisy voice, they dislike listen the English movie, English song and others, they do not see to the object directly, suddenly, there is someone come to their class and they cannot move their place, they do not have many vocabulary, they do not prepare the material before, sometimes, the situation is crowded, they are also sometimes disturbed by their friends, and another factor is they are busy to talk with their friends, they are lazy, tired and bored to listen.

The researcher gets this explanation from direct interview with sixteen the visual students in F listening class at the third semester students of IAIN Madura. Some of them are:

Saimatul Fadilah' statement is:

"I did not like listening. In the listening class just listened the material. My lecturer seldom used the picture and movie. The speaker was very fast. The voice of speaker was not clear to me (Fadilah, 2014)."

That statement same with Khairul Anwar, that is:

"I did not like listening, there was noisy voice from my headset and the speaker was very fast. I seldom listened the native speaker, there was no text and my friend disturbed me when I listened (Anwar, 2014)."

This is the statement is from Istifaiyah:

"I did not like listening but I like speaking. I seldom listened the native speaker and my friend asked to talk with me. When I was sleepy and hungry. The situation was crowded and sound of handphone. I could not move my place(Istifaiyah, 2014)."

All of the statement above strengthened with the direct observation by the researcher in the field. That are:

Saimatul Fadilah (35):

When she listened to the material, she wanted her lecturer to repeat the cassete.

Khairul Anwar (9):

When he listened to the material, he could not answer the question from his lecturer.

Istifaiyah (8):

When she listened to the material, she talked and discussed with her friend. 
All of the statement from sixteen visual students in $\mathrm{F}$ listening class at the third semester students of IAIN Madura same with the statement from their lecturer. Their lecturer is miss Kristanti Ayuanita, she said that:

"They were difficult to listen because they seldom listened the native speaker and they did not like listening. They dislike listened the English movie and the English song. They did not have listening habit. Beside that, because of the curriculum, there was just two listening subject, the first listening conducted in the second semester and the second listening conducted in the third semester like now. They never got the English news. Listening skill seldom to be discussed. They interested to another skill. Actually, the material in the handout often repeatedly. The content of material in the handout was a half material in the listening 1 and the others was the material of listening 2, but they were still difficult to comprehend the material. Beside that, I gave them warming up or brain storming before start to listen the material, gave them some task in the outside so they was not only listen the material in the classroom but also they can listen in the outside, gave them exercises and explain the difficult word. Sometimes, I repeated the cassete three till four times and paused the cassete. I did it because I wanted my students have the ability and skill in the listening (Ayuanita, 2014)."

It means that the lecturer explain that her students do not like listening, they interest to another skill, they seldom listen to the native speaker.

\section{Discussion}

In this case the researcher will describe the visual students learning in the listening class at the third semester students of IAIN Madura that related with the theory which has explained above. Almost visual students in F listening class like doodle or write something in their book. Beside that, they try to focus listen and concentration to the material because if they can not focus to the material so they can not understand it (Rabbianty, 2015). If they can not understand the material, they can not respond and answer the question from their lecturer so they can not develop other skill of language that is speaking skill. Beside that, they will confuse in the classroom and they can not continue to the others material. They have to know the vocabulary and the meaning. It helps them to understand more the material. If they can not understand the vocabulary they will translate them into Indonesia. In addition, they are aware of their pronounciation and the speaker's pronounciation. Some of them like movies. They try to understand the material, understand the vocabulary and etc. Actually, there are two visual students in F listening class at the third semester students of IAIN Madura that they do not like movies. They do not like movie because when they listened and watched the movie they can not get the point of material that they heard. So, the researcher found a new theory that not all visual students in F listening class like watch movies that related with the material of listening.

The next, the researcher will analyze the difficulties faced by the visual students that related with the theory which has explained above. Many kinds of difficulties faced by the visual students. Some of them are difficult to focus listen, difficult to concentration when they listened the material Some of them difficult to answer the question from lecturer 
directly. Because they like written assignment then oral assignment and etc. In this part, the researcher found a new theory that there are two visual students have not problem with verbal instruction except in the written form. They prefer oral assignment than written assignment. Oral assignment it easier than written because they can answer the question directly and they do not need long time to think. While, written assignment need long time to think. So, not all visual students in F listening class have problem or difficult with the verbal or oral instruction. Beside that, other new theory that found by the researcher is there are three visual students in F listening class at the third semester students of IAIN Madura that they are not loss their concentration when they paid attention to the material and their concentration can not disturb with others. So, they always concentrate although want to give attention.

And the last the researcher will explain about the factors that make the visual students difficult to comprehend the material with theory which has explained above. Many factors that make the visual students in F listening class difficult to understand the material. All of the difficulties faced by the visual students caused by: some of them donot like listening, they seldom listen to the native speaker, they interest to another skill of language. They can not hear the voice of speaker clearly and there is noisy voice and etc. In fact, ten of sixteen's statements of visual students in F listening class at the third semester students of IAIN Madura, the factor that make them difficult to understand the material is the situation is noise or crowded. It means that they can not learn in the noise or crowded situation. It is different with the theory which has explained in the previous chapter. It means that the most factor that make the visual students in F listening class at the third semester students of IAIN Madura difficult to comprehend the material because the situation is noise or crowded. Beside that, the noisy voice is from their friends, earphone and sound of handphone. So, the researcher found a new theory that is not all visual students in F listening class at the third semester students of IAIN Madura can learn in the noise or crowded situation. Truly, Mrs. Kristanti Ayuanita is the lecturer of F listening class at the third semester students of IAIN Madura. She helps her students in listening class such as give the students warming up or brain storming before start to listen the material, give them some task in the outside so they are not only listen the material in the classroom but also they can listen in the outside. Beside that, she gives her students exercises and explain the difficult word. She repeats the cassete three till four times and pause the cassete. She carries out many ways to the student's progress in the listening because she wants her students can master the listening skill of language.

\section{CONCLUSION}

Based on the result and discussion of research,the researcher can conclude that Almost visual students in F listening class like doodle or write something in their book. They try to focus listen and concentration to the material, they are silent, they emember 
the vocabulary easily, they are focus to see the material in their book, they read the material, they try to understand the material and understand the vocabulary, they understand the picture in their handout, they look for the meaning of vocab in the dictionary, and hey ask the meaning to their friend and talk or discuss about the meaning of vocabulary. Many Kinds of Difficulties Faced by the Visual Students in Listening Class are they are difficult to concentrate in the listening class and they do not understand the previous material so difficult to continuo other material, they are difficult to focus listening and answering the question from lecturer directly. They are difficult to understand the vocabulary, pronunciation, catching the point, and etc. Some of the factors cause them difficult to understand listening materials are they do not like listening, they can-not hear the voice of speaker clearly, besides that some environmental causes like noisy, crowded, disturbance from other students, etc.

\section{REFERENCES}

Creswell, J. W. (2012). Education Research. Boston: Pearson Education.

Davir, R. A. M. (2014, October 31). The student of listening class at the third semester students of STAIN Pamekasan [Direct Interview].

Deporter, B. (2000). Quantum Teaching. Bandung: PT. Mizan Pustaka.

Deporter, B., \& Henarcki, M. (2000). Quantum Learning. Bandung: PT. Mizan Pustaka.

Everest, F. A. (2007). Critical Listening Skills for Audio Professionals. Boston: Thomson Course Technology.

Fleetham, M. (2006). Multiple Intelligence in Practice. Stafford: Network Continuum Education.

Gardner, H. (1983). Frames of Mind. New York: A Member of the Perseus Books Group.

Gunawan, A. W. (2004). Genius Learning Strategy. Jakarta: PT. Ikrar Mandiri Abadi.

Hoerr, T. R., \& Rolheiser-Bennett, N. C. (2000). Becoming a Multiple Intelligences School. Beauregard St: ASCD.

Maufiroh, S. (2012). Some Problem in Learning Listening Comprehension Faced by The Eight Grade Students at MTs Al-Falah Al-Islami Bancelok Jrengik Sampang (Unpublished Thesis). STAIN Pamekasan.

Miles, M. B., \& Huberman, A. M. (1994). Qualitative Data Analysis (2nd ed.). London: SAGE Publications.

Moleong, L. J. (2014). Metodologi Penelitian Kualitatif. Bandung: Remaja Rosdakarya.

Mortimore, T. (2008). Dyslexia and Learning Style: A Practitioner's Handbook (2nd ed.). Chichester: John Wiley \& Sons.

Rabbianty, E. N. (2013). English Teaching and Learning Theories. Pamekasan: STAIN Pamekasan Press.

Rabbianty, E. N. (2015). DI SEKOLAH ALAM EXCELLENTIA PAMEKASAN MADURA. 1, 20.

Rahmadhani, A. (2013). The Effect of Blind Map as the Instructional Media on Students Listening Comprehension of Seventh Grade of SMPN 5 Pamekasan (Unpublished Thesis). STAIN Pamekasan. 
Isrok Wulandari, and Kristanti Ayuanita, The Visual Students' Problems ...

Worthington, D., \& Fitch-Hauser, M. (2012). Listening: Processes, Functions and Competency. Boston: Pearson Education Inc.

\section{Interview Source:}

Anwar, K. (2014, November 19). The student of listening class at the third semester students of STAIN Pamekasan [Direct Interview].

Ayuanita, K. (2014, December 3). The lecturer of listening class at the third semester students of STAIN Pamekasan [Direct Interview].

Davir, R. A. M. (2014, Oktober). The student of listening class at the third semester students of STAIN Pamekasan [Direct Interview].

Fadilah, S. (2014, November 19). The student of listening class at the third semester students of STAIN Pamekasan [Direct Interview].

Hifni, M. (2014, November 5). The student of listening class at the third semester students of STAIN Pamekasan [Direct Interview].

Isnaini, N. (2014, Oktober). The student of listening class at the third semester students of STAIN Pamekasan [Direct Interview].

Istiana. (2014, November 5). The student of listening class at the third semester students of STAIN Pamekasan [Direct Interview].

Istifaiyah. (2014, November 12). The student of listening class at the third semester students of STAIN Pamekasan [Direct Interview]. 